\title{
Side chain polysiloxanes with phthalocyanine moieties
}

\author{
T. Ganicz*, T. Makowski, W. A. Stanczyk, A. Tracz \\ Centre of Molecular and Macromolecular Studies, Polish Academy of Sciences, Sienkiewicza 112, 90-363 Lodz, Poland
}

Received 7 September 2011; accepted in revised form 30 November 2011

\begin{abstract}
Side chain polysiloxane with 5-(pentyloxy)-3-methyloxy-9,10,16,17,23,24-hexakis(octenyloxy)phthalocyanine moieties is synthesized by hydrosilylation reaction. The phase behavior and thermooptical properties of the polysiloxane and starting 2-(pent-4-enyloxy)-3-methyloxy-9,10,16,17,23,24-hexakis(octenyloxy)phthalocyanine is examined by POM (Polarizing optical microscopy), TOA (thermooptical analysis), DSC (differential scanning calorimetry), AFM (atomic force microscopy) and SAXS (small angle X-ray scattering) studies. The effect of the attachment of phthalocyanine to polysiloxane chains over phase transitions and phase morphology is discussed in details.
\end{abstract}

Keywords: thermal properties, polysiloxanes, phthalocyanines, electro-optical properties, polymer synthesis

\section{Introduction}

Phthalocyanines are one of the most studied classes of organic functional materials with high potential in electrooptics. Due to their 18-p electron macrocyclic aromatic system, closely related to that of the naturally occurring porphyrin ring, and relative facile tailoring of molecular structure by chemical modification, they found numerous commercial applications, among others: photoconductors in xerography [1], optical data storage [2], solar energy conversion [3], electrochromic and electroluminescent displays [4].

One of the most studied area of the application of phthalocyanines are organic thin film transistors (OTFT) as a potential replacement for silicon-based devices [5], as well as new electronic devices based on field transistor technology such as electronic paper [6] and various types of sensors [7].

Usefulness of low molecular phthalocyanines as a material for OTFT sensors has been already proved [8], however in many cases mechanical resistance of their thin films is not satisfactory. In order to improve mechanical properties of these materials it is possible to polymerize them or attach them as a side chains to various polymer main chains. Such the polymers may also have an increased tendency to form columnar or calamitic mesophases which might help to obtain thin films with high order of molecular self-organization. However most of the phthalocyanine polymers studied till now, exhibit too high transition temperatures and too low solubility to be used for formation of thin films with good mechanical resistance [9].

Therefore, it was decided to attach phthalocyanines as side chains to polysiloxane, the backbone well known for its high flexibility, leading thus, to materials with lower transition temperatures compared to other polymers [10].

\section{Experimental section}

\subsection{Materials and methods}

\subsubsection{Substrates}

All organometallic syntheses were carried out under argon with exclusion of moisture. Catehol (Aldrich, Germany), Guajacol (Aldrich), bromine ('Polskie Odczynniki Chemiczne' - POCh, Poland), glacial

\footnotetext{
${ }^{*}$ Corresponding author, e-mail: $\operatorname{tg@cbmm.lodz.pl~}$

(c) BME-PT
} 
acetic acid (POCh), $\mathrm{NaHCO}_{3}(\mathrm{POCh}), \mathrm{K}_{2} \mathrm{CO}_{3}$ (POCh) $\mathrm{MgSO}_{4}$ (POCh), $\mathrm{FeCl}_{3}$ (POCh), $\mathrm{HCl}$ aq. 37\% (POCh), 1-bromo-octane (Aldrich), ethanol absolute (POCh), DBN (Aldrich), chloroform (POCh), poly(methylhydrolsiloxane) 30cSt. (ABCR, Germany), 3,6-dihydroxyphthalonitrile (Aldrich) have been used as supplied.

Methylene chloride (POCh), toluene (POCh), DMF (dimethylformamide, POCh) were dried by standard methods and stored over molecular sieves or sodium mirror [11].

4,5-dibromocatehol [12], 4,5-dihydroxyphthalonitrile [13], 4,5-dibromo-2-methoxyphenol [14], 4hydroxy-5-methoxyphthalonitrile [12] were obtained as described elsewhere.

\subsubsection{Spectroscopy}

The ${ }^{1} \mathrm{H}-,{ }^{13} \mathrm{C}$ - and ${ }^{29} \mathrm{Si}-\mathrm{NMR}$ spectra were recorded in $\mathrm{CDCl}_{3}$ solutions with a Bruker AC 200 or a Bruker DRX 500 spectrometers. IR spectra were obtained with an ATI Mattson spectrometer for polymer solutions in sodium dried toluene.

\subsubsection{Molecular weight measurement}

Molecular weights were determined by gel-permeation chromatography (GPC) using a Waters system with Wyatt/Optilab 902 Interferometric Refractometer, calibrated for monodisperse polystyrene standards.

\subsubsection{Thermooptical analysis (TOA)}

Changes of the transmission of polarized light in a function of temperature were recorded and visualized using a home made program. Simultaneously the morphology of thin layers was observed under optical microscope. Morphology of samples was studied using Nikon Eclipse E400 Pol microscope equipped with polarizing filters and an analog SANYO VCC-3770P camera. The images were acquired using Leadtek TV Tuner WinFast PVR2. Heating and cooling of the samples at a controlled rate was accomplished using Mettler FP82 hot stage equipped with an FP90 controller and a photo detector.

\subsubsection{Differential scanning calorimetry (DSC)}

Differential scanning calorimetry (DSC) studies were performed using TA Instruments DSC-2920 and DuPont DSC-910, calibrated with an indium standard.

\subsubsection{Atomic Force Microscopy (AFM)}

Atomic force microscopy (AFM) images were recorded under ambient atmosphere, at room temperature, using Nanoscope IIIa, MultiMode (Veeco, Santa Barbara, CA) microscope. The probes were commercially available rectangular silicon cantilevers (RTESP from Veeco) with nominal radius of curvature in the $10 \mathrm{~nm}$ range spring constant 20 $80 \mathrm{~N} / \mathrm{m}$, a resonance frequency lying in the 264 $369 \mathrm{kHz}$. The images were recorded with the highest available sampling resolution, that is, $512 \times 512$ data points.

\subsubsection{Small angle $X$-ray scattering (SAXS)}

For small angle X-ray scattering (SAXS) $0.5 \mathrm{~m}$ long Kiessig-type camera equipped with a pinhole collimator and a Kodak imaging plate as recording medium was used. The camera was coupled to the Philips PW 1830 X-ray generator $\left(\mathrm{Cu} \mathrm{K}_{\alpha}\right.$ operating at $50 \mathrm{kV}$ and $30 \mathrm{~mA}$ ) consisting of a capillary collimator. Exposed imaging plates were read with PhosphorImager Si system (Molecular Dynamics). Thin layer of Polymer 1 was deposited on a kapton foil.

\subsection{Syntheses}

4,5-Bis-octyloxy-phthalonitrile (sub. 1)

A mixture of $1.95 \mathrm{~g}(14.1 \mathrm{mmol})$ of $\mathrm{K}_{2} \mathrm{CO}_{3}, 1.87 \mathrm{~g}$ (11.68 mmol) 4,5-dihydroxyphthalonitrile and $4.6 \mathrm{~g}$ $(23.81 \mathrm{mmol})$ of 1-bromooctane in $80 \mathrm{ml}$ of dry DMF was refluxed under argon for $7 \mathrm{hrs}$. After cooling to r.t. $150 \mathrm{ml}$ of water and $150 \mathrm{ml}$ of methylene chloride were added and the mixture was stirred for $30 \mathrm{~min}$. The aqueous (top) layer was extracted with $100 \mathrm{ml}$ of methylene chloride. Combined organic layers were washed with $50 \mathrm{ml}$ of 5\% $\mathrm{NaHCO}_{3}$ aq. twice, and dried over $\mathrm{MgSO}_{4}$ overnight. The mixture was filtered, and the solvent was evaporated. Brown residue was purified on silica column (eluent: chloroform/ethyl acetate) and dried in vacuum $\left(60^{\circ}, 1 \mathrm{mmHg}, 3 \mathrm{hrs}\right)$ leaving $3.15 \mathrm{~g}$ (yield: $70.1 \%)$ of white solid. M.p: $107^{\circ} \mathrm{C},{ }^{1} \mathrm{H}$ NMR $\left(200 \mathrm{MHz}, \mathrm{CDCl}_{3}, \delta\right.$ ): 0.88 (t, $\left.6 \mathrm{H}, \mathrm{CH}_{3}\right), 1.20-1.50$ (m, $\left.24 \mathrm{H}, \mathrm{C}-\mathrm{CH}_{2}-\mathrm{C}\right), 4.0\left(\mathrm{t}, 4 \mathrm{H}, \mathrm{CH}_{2}-\mathrm{O}\right), 7.24$ (m, $2 \mathrm{H}, \mathrm{Ph}-\mathrm{H}),{ }^{13} \mathrm{C}$ NMR $(200 \mathrm{MHz}$, standard proton decoupling, $\mathrm{CDCl}_{3}, \delta$,): $14.1\left(\mathrm{CH}_{3}\right), 23.1,26.2$, 31.9, 29.3, 29.5, 26.4, 31.6, $\left(-\left(\mathrm{CH}_{2}\right)_{\mathrm{x}}-\mathrm{CH}_{3}\right), 69.8$ $\left(\mathrm{O}-\mathrm{CH}_{2}\right), 117.9$ (aromatic carbons), anal. calcd for $\mathrm{C}_{24} \mathrm{H}_{36} \mathrm{~N}_{2} \mathrm{O}_{2}$ : C 74.96, H 9.44 N 7.28; found: C 75.2, H 9.2, N 7.3 
4-Methoxy-5-pent-4-enyloxy-phthalonitrile (sub. 2) The synthesis and purification were performed using the procedure described for 4,5-bis-octyloxy-phthalonitrile. A mixture of $3 \mathrm{~g}(17.22 \mathrm{~mol})$ of 4-hydroxy5-methoxy-phthalonitrile, $2.67 \mathrm{~g}(17.43 \mathrm{mmol})$ of 5-bromo-pent-1-ene and $2.87 \mathrm{~g}$ of $\mathrm{K}_{2} \mathrm{CO}_{3}$ in $150 \mathrm{ml}$ of DMF after $7 \mathrm{hrs}$. of refluxing and purification yielded $3.21 \mathrm{~g}(77 \%)$ of white solid. M.p: $131^{\circ} \mathrm{C}$, ${ }^{1} \mathrm{H}$ NMR $\left(200 \mathrm{MHz}, \mathrm{CDCl}_{3} \delta\right): 1.32(\mathrm{~m}, 2 \mathrm{H}$, $\left.\mathrm{O}-\mathrm{C}-\mathrm{CH}_{2}\right), 1.98\left(\mathrm{~m}, 2 \mathrm{H}, \mathrm{O}-\mathrm{C}-\mathrm{C}-\mathrm{CH}_{2}\right), 3.95$ (s, $\left.3 \mathrm{H}, \mathrm{CH}_{3}\right), 4.07\left(\mathrm{t}, 2 \mathrm{H}, \mathrm{O}-\mathrm{CH}_{2}\right), 4.95-5.15(\mathrm{~m}, 2 \mathrm{H}$, $\left.\mathrm{HC}=\mathrm{CH}_{2}\right), 5.70-5.90\left(\mathrm{~m}, 1 \mathrm{H}, \mathbf{H C}=\mathrm{CH}_{2}\right), 7.11,7.26$ (m, 2H, Ph-H), ${ }^{13} \mathrm{C}$ NMR (200 MHz, standard proton decoupling, $\mathrm{CDCl}_{3}, \delta$,): $29.5\left(\mathrm{CH}_{2}-\mathrm{CH}=\mathrm{CH}_{2}\right)$, $31.1\left(\mathrm{CH}_{2}-\mathrm{CH}_{2}-\mathrm{CH}=\mathrm{CH}_{2}\right), 56,1\left(\mathrm{OCH}_{3}\right), 69.2$ $\left(\mathrm{O}-\mathrm{CH}_{2}\right), 115.4\left(\mathrm{CH}=\mathrm{CH}_{2}\right), 117.6,118.2$ (aromatic carbons), $137.8 \quad\left(\mathrm{CH}=\mathrm{CH}_{2}\right)$, Anal. calcd for $\mathrm{C}_{15} \mathrm{H}_{16} \mathrm{~N}_{2} \mathrm{O}_{2}$ : C 70.29, H 6.29, N 10.93; found: C 69.9, H 6.1, N 11.1

2-(pent-4-enyloxy)-3-methyloxy-9,10,16,17,23,24hexakis(octenyloxy)phthalocyanine (sub. 3)

A mixture of $7.9 \mathrm{~g}$ (20.5 mmol) of 4,5-bis-octyloxyphthalonitrile, $1.65 \mathrm{~g}(6.8 \mathrm{mmol})$ of 4-methoxy-5pent-4-enyloxy-phthalonitrile and $3.28 \mathrm{~g}$ of DBN in $70 \mathrm{ml}$ of dry ethanol was refluxed for $36 \mathrm{hrs}$. After cooling down the mixture was diluted with $20 \mathrm{ml}$ of chloroform. $300 \mathrm{ml}$ of acetone was added and the mixture was stirred at r.t. for $30 \mathrm{~min}$. The green precipitate was filtered, washed with acetone, dried and isolated on silica column (eluent: chloroform/ methylene chloride) . Yield: $1.3 \mathrm{~g}(13.7 \%) .{ }^{1} \mathrm{H}$ NMR: $\left(200 \mathrm{MHz}, \mathrm{CDCl}_{3} \delta\right): 0.88$ (t, $\left.18 \mathrm{H}, \mathrm{C}-\mathrm{CH}_{3}\right), 1.21-$ $1.71\left(\mathrm{~m}, 36 \mathrm{H},-\mathrm{C}-\mathrm{CH}_{2}-\mathrm{C}\right.$ from octenyloxy side chains), $1.85-1.91\left(\mathrm{~m}, 10 \mathrm{H},-\mathrm{C}-\mathrm{CH}_{2} \mathrm{C}-\mathrm{O}\right), 2.02$ (m, C-CH $-\mathrm{C}=\mathrm{C}), 3.35\left(\mathrm{~s}, 3 \mathrm{H}, \mathrm{OCH}_{3}\right), 3.95-4.12$ (m, $\left.14 \mathrm{H}, \mathrm{O}-\mathrm{CH}_{2}\right), 4.90-5.05\left(\mathrm{~m}, 2 \mathrm{H}, \mathrm{HC}=\mathrm{CH}_{2}\right)$, 5.65-5.75 $\left(\mathrm{m}, 1 \mathrm{H}, \mathbf{H C}=\mathrm{CH}_{2}\right), 7.31-7.36(8 \mathrm{H}$, Phtalocy-H), ${ }^{13} \mathrm{C}$ NMR $(200 \mathrm{MHz}$, standard proton decoupling, $\mathrm{CDCl}_{3}, \delta$,): $14.1\left(\mathrm{CH}_{3}-\left(\mathrm{CH}_{2}\right)_{7}\right), 22.7$, 26.9, 29.3, 29.8, 30.4, 31.8, $\left(\mathrm{CH}_{3}-\left(\mathrm{CH}_{2}\right)_{6}-\mathrm{CH}_{2}\right)$, 28.8, $30.4\left(\mathrm{H}_{2} \mathrm{C}=\mathrm{CH}-\left(\mathrm{CH}_{2}\right)_{2}\right), 55.8\left(\mathrm{OCH}_{3}\right), 69.2$ $\left(\mathrm{H}_{2} \mathrm{C}=\mathrm{CH}-\left(\mathrm{CH}_{2}\right)_{2}-\mathrm{CH}_{2} \mathrm{O}\right), 69.5\left(\mathrm{CH}_{3}-\left(\mathrm{CH}_{2}\right)_{6} \mathrm{CH}_{2} \mathrm{O}\right)$, 95.3, 95.5, 102.7, 105.5,106.9 (aromatic carbons), $115.4\left(\mathrm{H}_{2} \mathbf{C}=\mathrm{CH}\right), 138.7\left(\mathrm{H}_{2} \mathrm{C}=\mathbf{C H}\right)$, anal. calcd for $\mathrm{C}_{86} \mathrm{H}_{122} \mathrm{~N}_{8} \mathrm{O}_{8}$ : C $74.00 \mathrm{H} 8.81 \mathrm{~N}$ 8.03; found: C 74, H 8.7, N 7.9
Hydrosilylation of 2-(pent-4-enyloxy)-3-methyloxy-9, 10,16,17,23,24-hexakis(octenyloxy)phthalocyanine with polymethylhydrosiloxane (Polymer 1)

$1 \mathrm{~g}(0.69 \mathrm{mmol})$ of 2-(pent-4-enyloxy)-3-methyloxy-9,10,16,17,23,24-hexakis(octenyloxy)phthalocyanine and $37 \mathrm{mg}\left(0.62 \mathrm{mmol}\right.$ of $\left[\mathrm{CH}_{3} \mathrm{Si}(\mathrm{H}) \mathrm{O}-\right]$ mers) of polymethylhydrosiloxane were dissolved in $15 \mathrm{ml}$ of dry toluene and stirred under argon. Platinum tetramethyldivinyldisiloxane (PTDD) complex in xylenes $\left(10^{-4} \mathrm{~mol} \mathrm{Pt} / \mathrm{mol} \mathrm{SiH}\right)$ was added and the reaction mixture was stirred at $60^{\circ} \mathrm{C}$. Reaction progress was followed by FTIR (disappearance of Si-H absorption band at $2150 \mathrm{~cm}^{-1}$ ). After $24 \mathrm{hrs}$. of reaction the conversion was $94.4 \%$. The reaction was stopped after $48 \mathrm{hrs}$, as there was no further progress after that time. Solvent was removed on vacuum, leaving green solid. The product was purified by multiple precipitation from dichloromethane/ methanol and dried $\left(75^{\circ} \mathrm{C}, 1 \mathrm{mmHg}\right)$. Yield $0.75 \mathrm{~g}$ (72\%). The structure was confirmed by ${ }^{1} \mathrm{H}$ NMR, (Figure 1), ${ }^{13} \mathrm{C}$ NMR $(200 \mathrm{MHz}$, standard proton decoupling, $\mathrm{CDCl}_{3}, \delta$, ): $-0.18\left(\mathrm{CH}_{3} \mathrm{Si}\right), 1.09\left(\mathrm{SiCH}_{2}\right)$, $14.11\left(\mathrm{CH}_{3}-\left(\mathrm{CH}_{2}\right)_{7}\right), 18.23\left(\mathrm{SiCH}_{2} \mathrm{CH}_{2}\right), 19.82$ $\left(\mathrm{SiCH}_{2} \mathrm{CH}_{2} \mathrm{CH}_{2}\right), 22.68,26.90,29.28,30.06,30.42$, $31.80 \quad\left(\mathrm{CH}_{3}-\left(\mathrm{CH}_{2}\right)_{6}-\mathrm{CH}_{2}\right), \quad 27.14$ $\left(\mathrm{SiCH}_{2} \mathrm{CH}_{2} \mathrm{CH}_{2} \mathrm{CH}_{2}\right), \quad 55.83 \quad\left(\mathrm{OCH}_{3}\right), \quad 69.5$ $\left(\mathrm{Si}-\left(\mathrm{CH}_{2}\right)_{4} \mathbf{C H}_{2} \mathrm{O}\right), \quad 77.24 \quad\left(\mathrm{CH}_{3}-\left(\mathrm{CH}_{2}\right)_{6} \mathbf{C H}_{2} \mathrm{O}\right)$, 95.17, 102.97, 105.29,106.97 (aromatic carbons) and ${ }^{29} \mathrm{Si}$ NMR: (500 MHz, INEPT, $\mathrm{CDCl}_{3} \delta$ ): -6 $\left(-[\mathrm{Si}(\mathrm{Me})(\mathrm{R}) \mathrm{O}]_{\mathrm{n}}-\right), M_{\mathrm{n}}=6350, M_{\mathrm{w}}=9400(\mathrm{GPC})$

\section{Results and discussion \\ 3.1. Synthesis}

From synthetic point of view the most difficult step is obtaining phthalocyanines with a single terminal alkenyloxy substituent, which can be later attached to polysiloxanes as a side chain via hydrosilylation reaction (Figure 2).

The synthetic pathway to obtain phthalocyanines with various substituents was based on J. F. van der Pol paper from 1989 [14]. Unfortunately, all the starting aromatic nitriles are not available commercially and their synthesis is a multi-step process. The subsequent step of the synthesis was a coupling reaction (Figure 3) of the 3:1 mixture of bis-octenyloxy- and methoxy-5-pent-4-enyloxy substituted nitriles leading to a mixture of various phthalocya- 

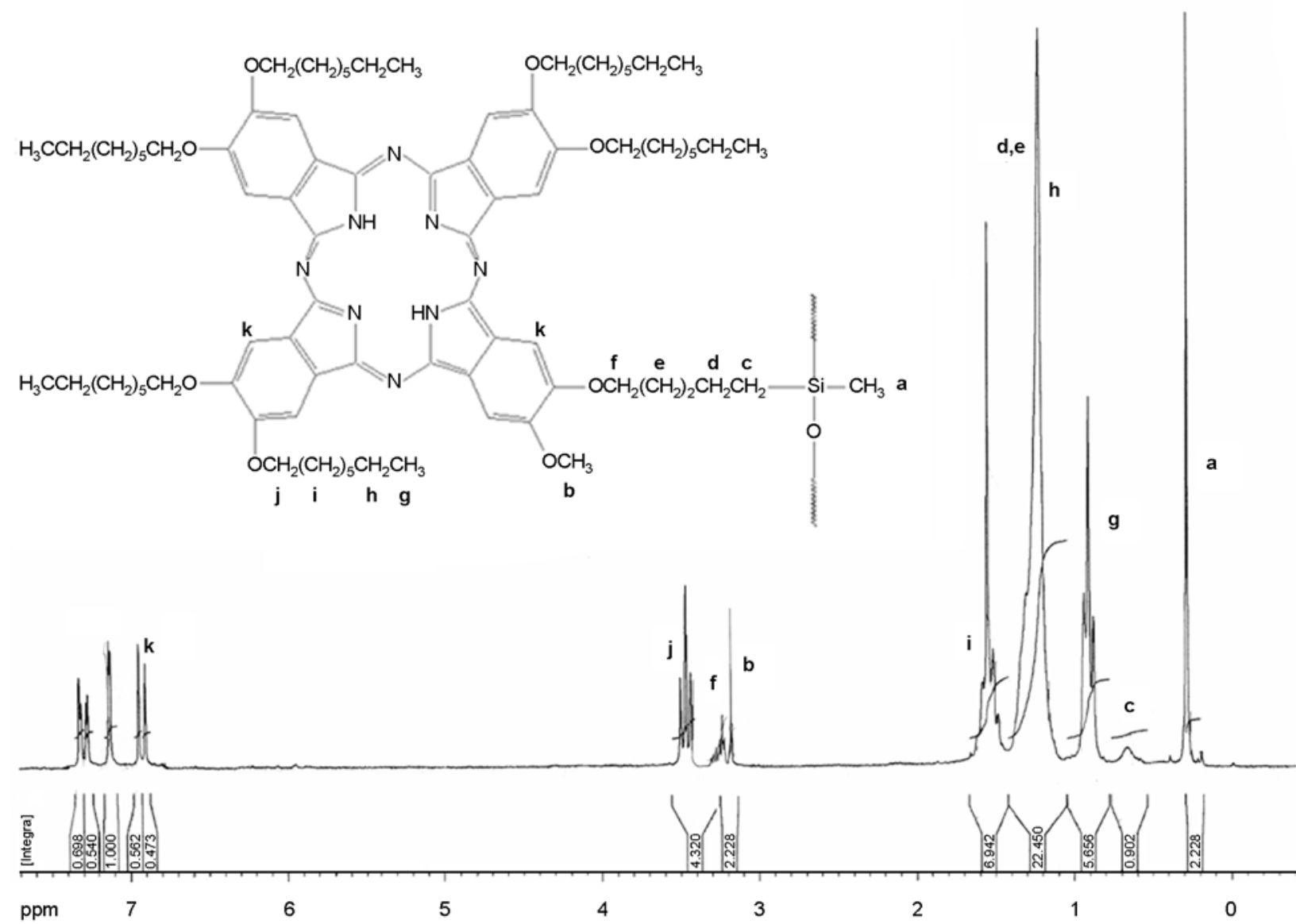

Figure 1. ${ }^{1} \mathrm{H}$ NMR (a) of Polymer 1

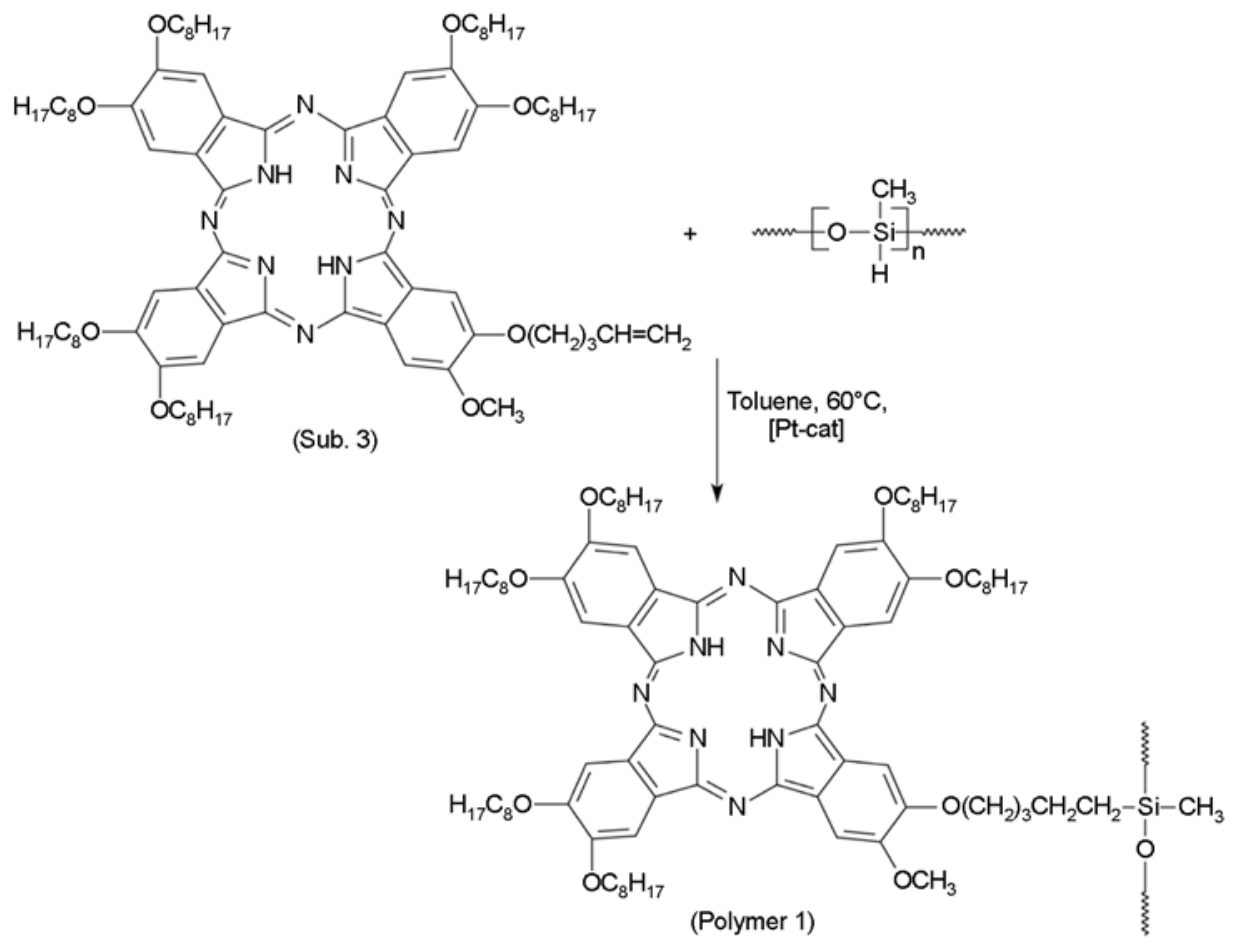

Figure 2. Synthetic pathway of side chain phthalocyanine substituted polysiloxane 

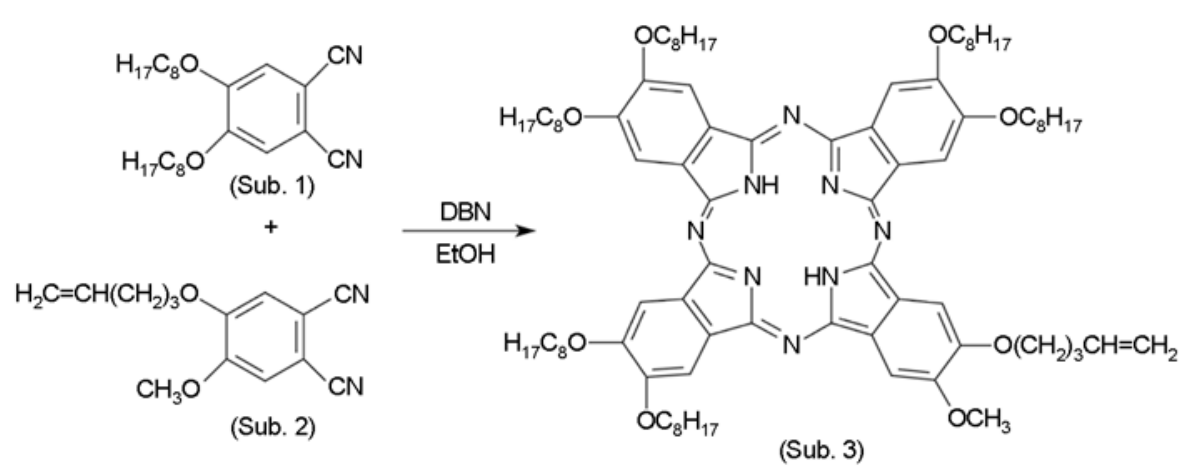

Figure 3. Synthetic route to of asymmetrically substituted phthalocyanines

nine products, which then had to be separated by column chromatography. The separation process was probably the main reason for low yields (11$13 \%$ ) of the expected products. They were, however, close to that reported by van der Pol et al. [14] for analogous compounds.

The attachment of the side phthalocyanine groups to the polysiloxane were performed in typical hydrosilylation conditions (toluene, Karstedt's catalyst, $\left.60-80^{\circ} \mathrm{C}\right)$. The conversion (94-95\%) after $24 \mathrm{hrs}$ (as proved by the disappearance of $\mathrm{Si}-\mathrm{H}$ signal at $2150 \mathrm{~cm}^{-1}$ in FTIR) was in rather typical range for hydrosilylation of alkenes bearing bulky groups [15]. As a result of the size of phthalocyanines higher level of the addition could not be obtained even after extended time of reaction (48 hrs). Although the final product contained 5\% of the unreacted $\mathrm{Si}-\mathrm{H}$ moieties, they were hydrolytically stable and we did not observe any crosslinking due to $\mathrm{Si}-\mathrm{H}$ hydrolysis and condensation of silanol groups even if the samples were heated up to $150^{\circ} \mathrm{C}$ or washed with water.

\subsection{Phase behaviour studies}

DSC measurements of Polymer 1, at a heating rate of $5^{\circ} \mathrm{C} / \mathrm{min}$ (curve 1 in Figure 4), revealed the endothermic phase transition at $70.8^{\circ} \mathrm{C}$ (enthalpy of $106.8 \mathrm{~J} / \mathrm{g}$ ). The transition corresponds to melting as confirmed by subsequent temperature optical analysis (TOA).

Upon cooling at rate of $5^{\circ} \mathrm{C} / \mathrm{min}$ (curve 2 in Figure 4), the exothermic peak (enthalpy of $95 \mathrm{~J} / \mathrm{g}$ ) corresponding to transition from isotropic liquid to organized structure was observed after large supercooling, at the temperature of $32.7^{\circ} \mathrm{C}$.

Polysiloxane used in the synthesis is amorphous, therefore the phase transition at $32.7^{\circ} \mathrm{C}$ must be

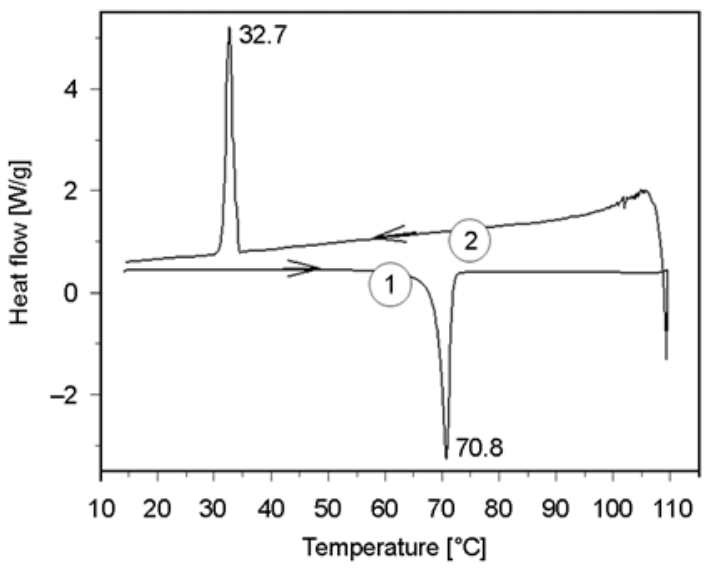

Figure 4. DSC thermogram of Polymer 1: curve 1 - heating; curve 2 - cooling

related to self-organization of phthalocyanine side groups. The result implies that the attachment of Pc via flexible spacer to the flexible polysiloxane does not preclude self-assembling of phthalocyanine discs.

It is worth noting that the enthalpy of the phase transitions at 70.8 and $32.7^{\circ} \mathrm{C}$ is much higher than usually observed for transitions of alkylated phthalocyanines from liquid crystalline state to isotropic melt and reverse [14, 16, 17]. It suggests the crystalline (not liquid crystalline) nature of Polymer 1. The phase transitions of Polymer 1 was independently studied by means of thermooptical analysis (TOA). Changes of the transmission of polarized light in function of temperature were recorded. Simultaneously the morphology of thin layers was observed under optical microscope. The layer of free, starting phthalocyanine compound (sub. 3) was also investigated for comparison.

The changes of the light intensity transmitted through layers of free phthalocyanine compound (sub. 3) and Polymer 1 upon heating at a rate of $5^{\circ} \mathrm{C} / \mathrm{min}$ and cooling at a rate of $5^{\circ} \mathrm{C} / \mathrm{min}$ (and of 

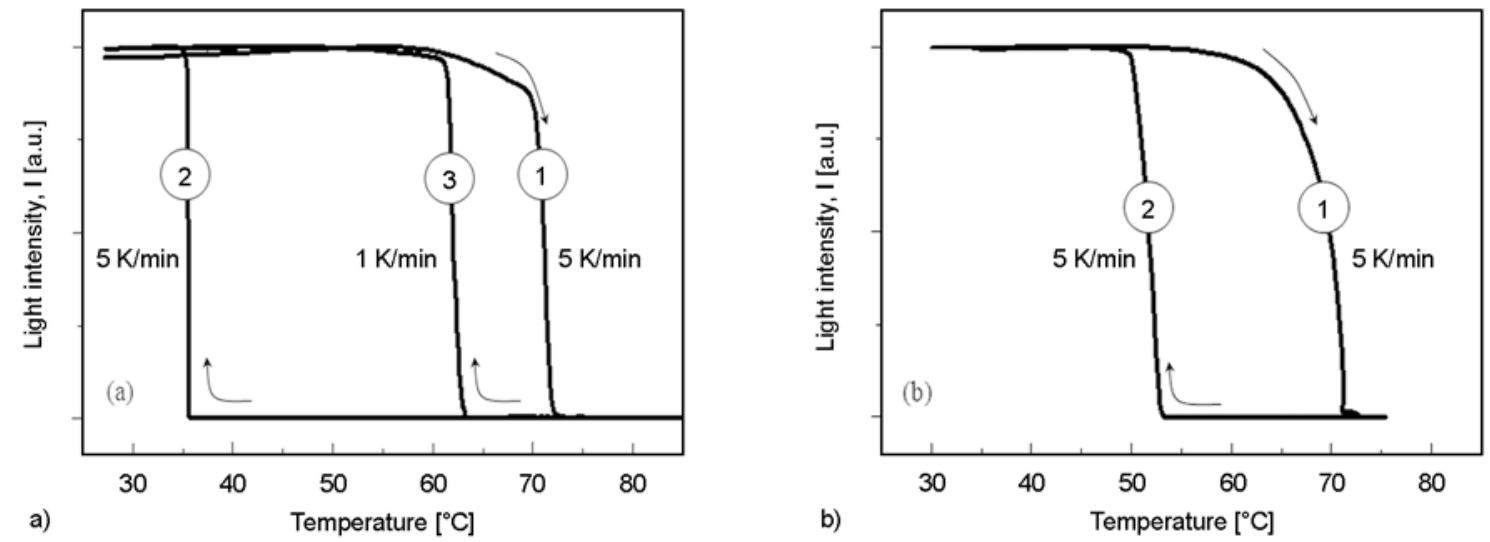

Figure 5. TOA curves for sub. 3. (a) and Polymer 1 (b). Heating and cooling rates are indicated.

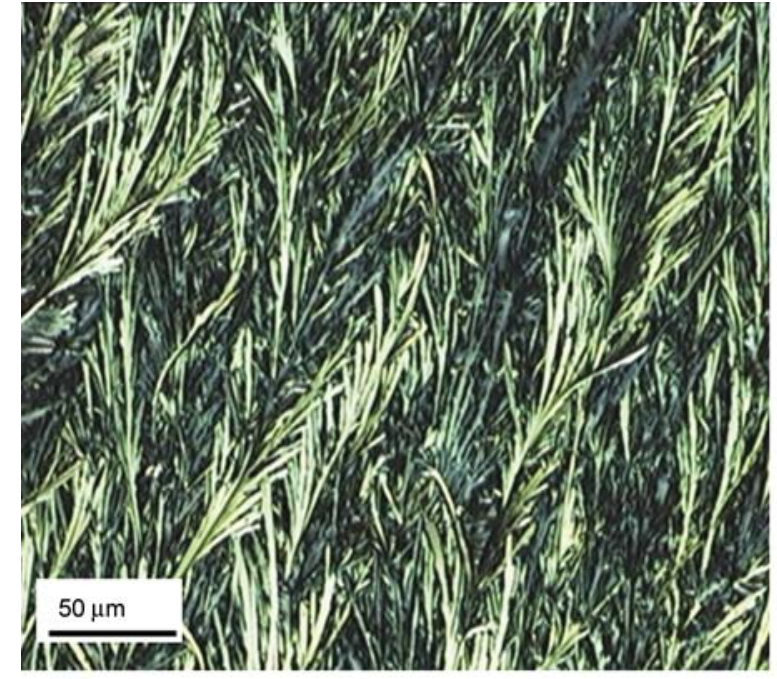

a)

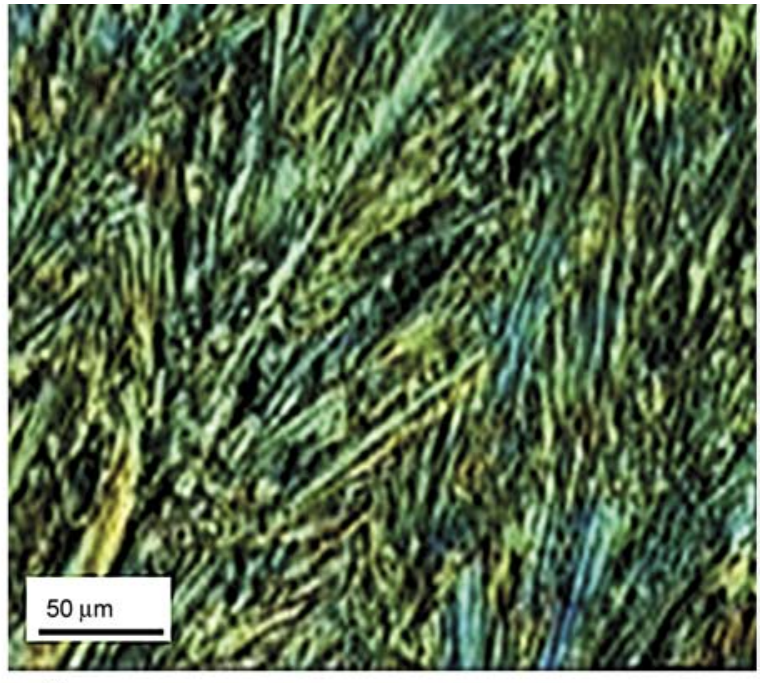

b)

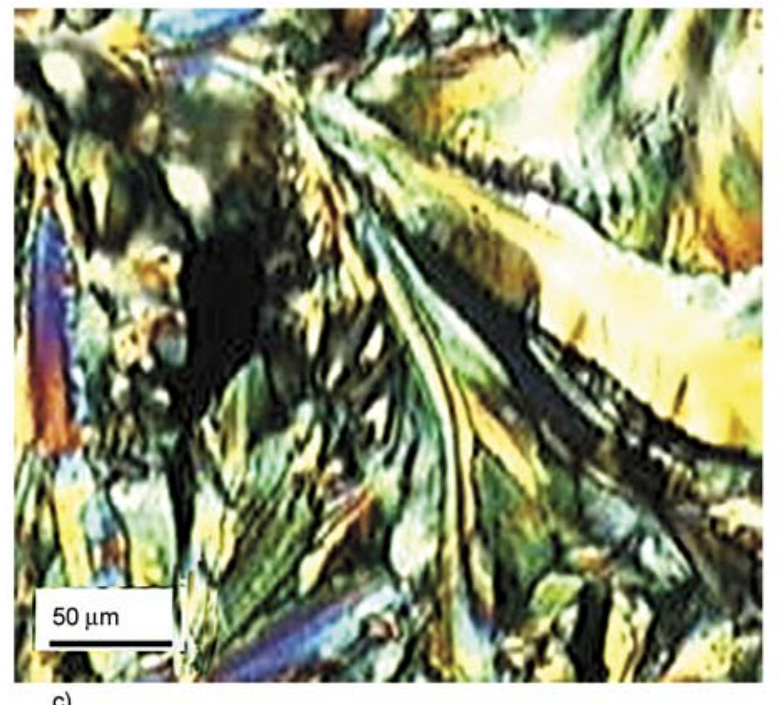

Figure 6. Room temperature morphology of thin sub. 3 and Polymer 1. layers (seen under crossed polarizes) after different thermal history: (a) - sub 3, cooling rate of $5 \mathrm{~K} / \mathrm{min}$; (b) - Polymer 1, cooling rate of $5 \mathrm{~K} / \mathrm{min}$ and (c) - Polymer 1 cooling rate of $1 \mathrm{~K} / \mathrm{min}$ 
$1^{\circ} \mathrm{C} / \mathrm{min}$ ) are shown in Figure 5). Images of samples showing morphology at room temperature (after cooling) are shown in Figure 6.

As one can see, upon heating of Polymer 1 at the rate $5^{\circ} \mathrm{C} / \mathrm{min}$ (curve 1 in Figure 5a) the intensity of the transmitted light starts to decrease slowly at $60^{\circ} \mathrm{C}$. A fast decrease is observed at ca $70^{\circ} \mathrm{C}$ when the melting temperature is reached.

Similar behavior (upon heating at a rate of $5^{\circ} \mathrm{C} / \mathrm{min}$ ) was observed for free phthalocyanine compound sub. 3 (compare curves 1 in Figure 5a and 5b).

It is worth noting that the melting temperatures for sub. 3 and Polymer 1 are practically identical. The results imply that the attachment of sub. 3 to a flexible polysiloxane chain does not affect the melting temperature of self-assembled phthalocyanine discs.

The difference between the two systems appears during cooling.

In the case of free phthalocyanine compound (sub. 3), upon cooling at the rate of $5^{\circ} \mathrm{C} / \mathrm{min}$, the light transmittance rises rapidly below $53^{\circ} \mathrm{C}$ (curve 2 in Figure 5). It is correlated with the growth of dendritic, highly birefringent structures (Figure 6a). Their growth is completed at ca. $49^{\circ} \mathrm{C}$.

Nucleation and growth of dendritic structures of Polymer 1 during cooling (at the same rate of $5^{\circ} \mathrm{C} / \mathrm{min}$ ) occurs at higher supercooling as compared with free sub. 3 (compare curves 2 in Figure $5 \mathrm{a}$ and $5 \mathrm{~b}$ ). The growth of dendritic structures of Polymer 1 starts at much lower temperature of

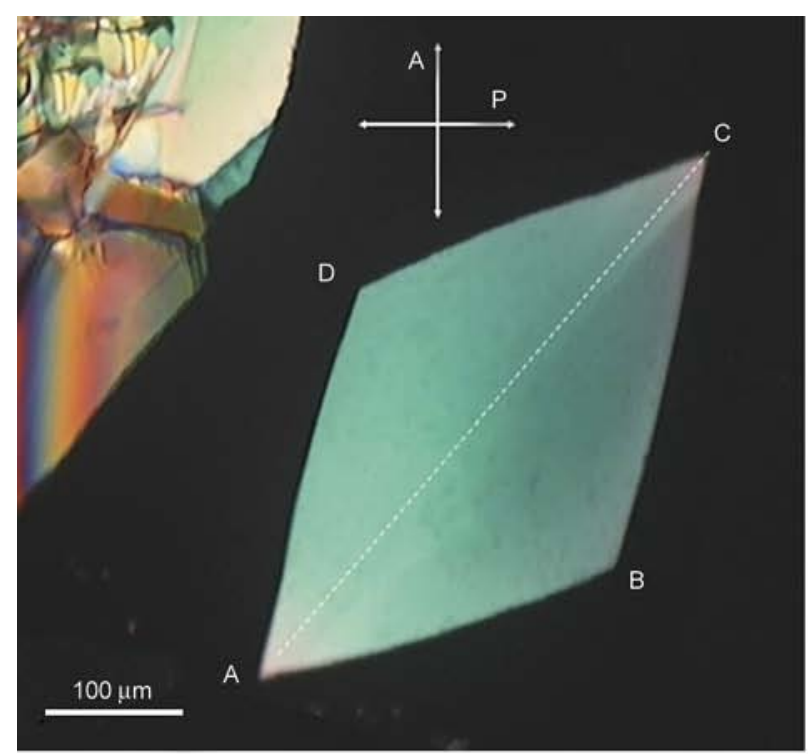

a) $36^{\circ} \mathrm{C}$. The branches forming dendrites are much thinner as compared with dendrites of free sub. 3 . This can be explained by their faster growth at higher supercooling under more diffusion limited conditions (compare Figure 6a and 6b). One can conclude that the attachment of sub. 3 to polysiloxane chain does not preclude the self-organization of discs, however it makes it more difficult (slower).

The temperature when self-assembling of Polymer 1 starts as well as the resulting morphology is strongly dependent on a cooling rate.

Upon cooling at lower rate of $1{ }^{\circ} \mathrm{C} / \mathrm{min}$ the supercooling of ca. $10^{\circ} \mathrm{C}$ is relatively small as compared with ca. $35^{\circ} \mathrm{C}$ for the cooling rate of $5^{\circ} \mathrm{C} / \mathrm{min}$ (com-

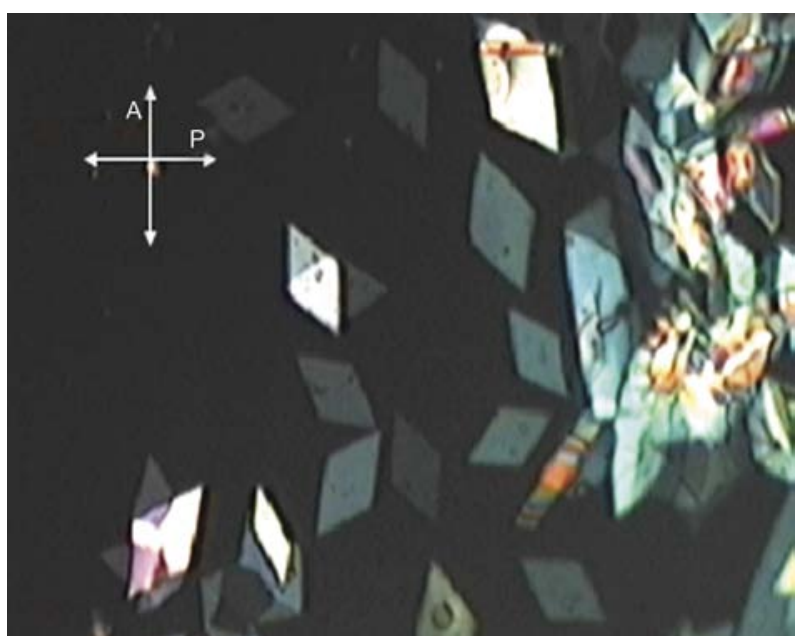

Figure 7. Rhomboidal plates of Polymer 1 growing isothermally at $69^{\circ} \mathrm{C}$ viewed under cross-polarization. The growing plates are embedded in melted Polymer 1 seen as a black medium.

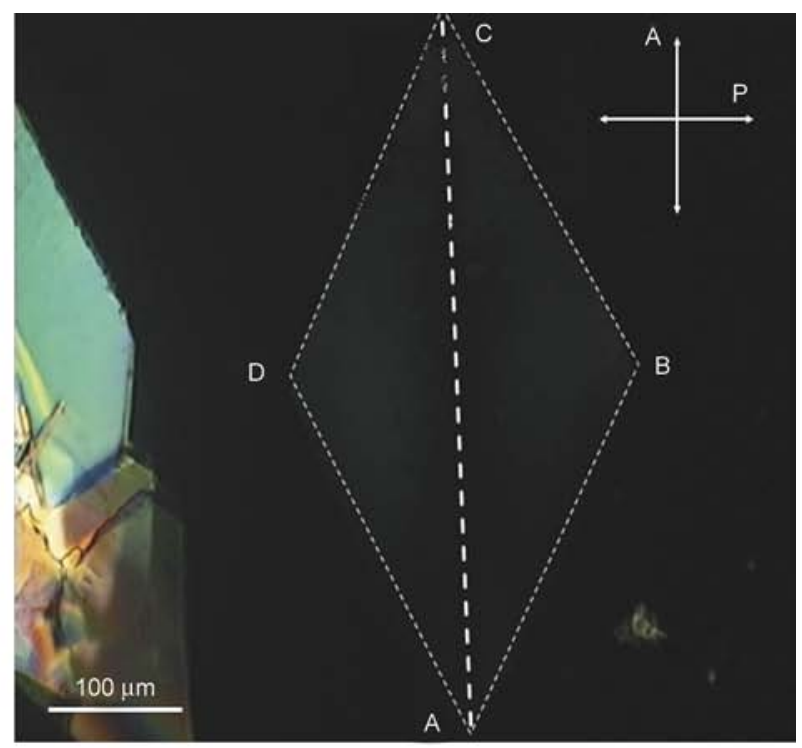

b)

Figure 8. The same rhomboidal plate of Polymer 1 seen between crossed polarizers at different orientation: (a) $45^{\circ}$ and (b) paralell to the polarizer 
pare curves 2 and 3 in Figure 5). The growth of more equilibrium (but still highly branched) leaflike structures (Figure 6c) is observed in the temperature range of $60-63^{\circ} \mathrm{C}$

Under isothermal conditions, at small supercooling, at the temperature of $69^{\circ} \mathrm{C}$, the growth of rhomboidal plates of Polymer 1 is observed (Figure 7). Such rhomboidal shape is uncommon for liquid crystalline materials. The shape together with the mentioned earlier high enthalpy of the phase transition and relatively large supercooling suggest the crystalline nature of the Polymer 1.

The plates are highly birefringent. As one can see in Figure 7 the light intensity transmitted by the plates under crossed polarizes strongly depends on their orientation.

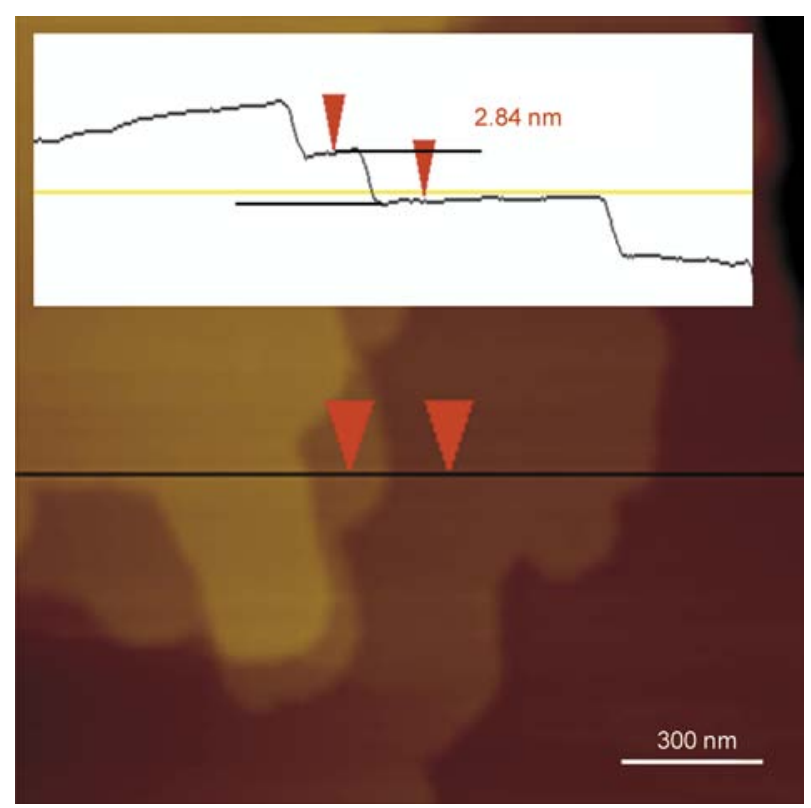

Figure 9. AFM image of the surface of Polymer 1 plate

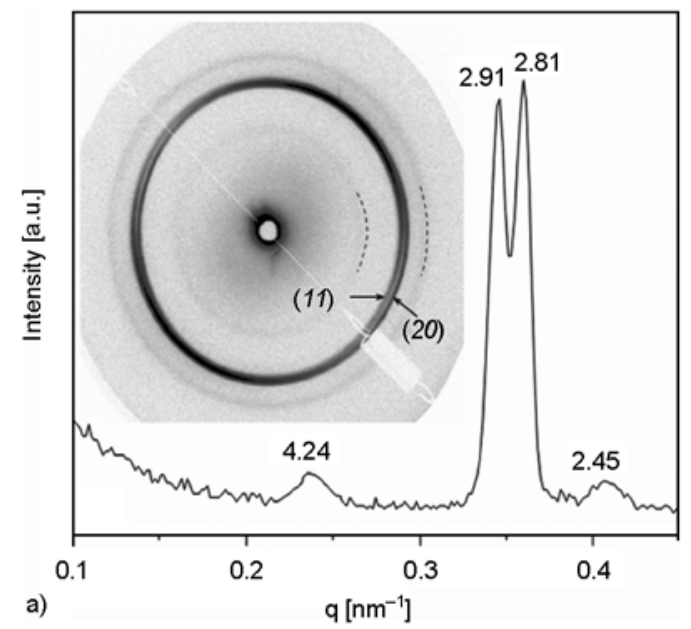

Figure 10. (a) - small X-ray diffraction pattern of layer of Polymer 1 deposited on kapton foil. (b) - proposed unit cell viewed along c-axis.

Images of the same rhomboidal crystalline plate 'ABCD' differently oriented with respect to polarized light are shown in Figure 8. The transmitted light intensity is the highest when the plate is oriented its diagonal $\mathrm{AC}$ at an angle of $45^{\circ}$ with respect to polarizer (Figure $8 \mathrm{a}$ ). No sectors are then visible, which means that phthalocyanine discs are uniformly organized within the plate (unique optical axis).

The plate is hardly seen when its diagonal is parallel to the polarizer (Figure 8b). It means that the optical axis is oriented parallely or perpendicularly to the diagonal AC.

One can expect that phthalocyanine discs, even attached as side groups to polymer chain via flexible spacer, form columns [14]. The result shown in Figure 8 implies that columns are uniformly oriented parallelly or perpendicularly to diagonal of the plate.

Despite our experience in imaging columns of discotic materials $[18,19]$ using AFM, we could not visualize columnar structure in the case of Polymer 1. We could however reveal the layer-like structure of the rhomboidal plates. The thickness of layers of ca. $2.9 \mathrm{~nm}$ was determined (Figure 9).

Thickness of ca. $2.9 \mathrm{~nm}$ (corresponding to the thickness of a single sheet of columns) is in a reasonable agreement with earlier measurements performed on layers of other similar phthalocyanines forming columns [19-22].

Postulated columnar structure of Polymer 1 was confirmed by preliminary X-ray diffraction studies. The result of small angle X-ray diffraction of thin layer of Polymer 1 at room temperature is shown in

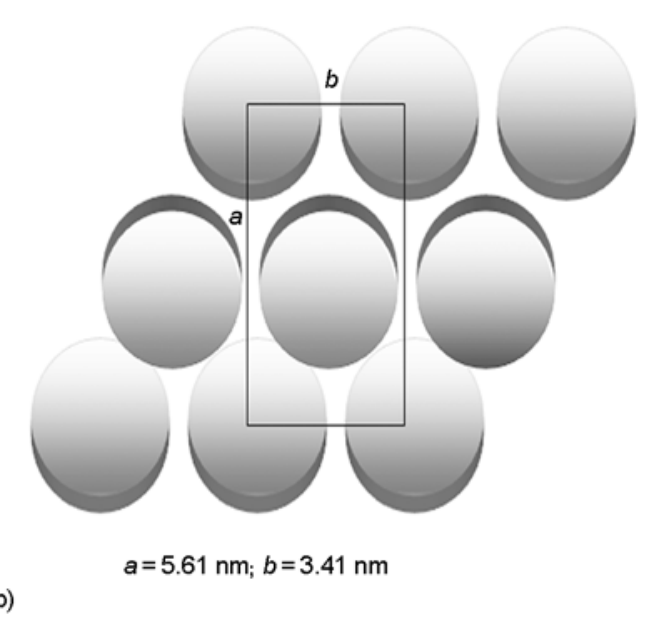

b) 
Figure 10a. The diffraction pattern is dominated by two peaks corresponding to periodicities of 2.91 and $2.81 \mathrm{~nm}$. These peaks can tentatively be ascribed to reflections from (11) and (20) planes assuming rectangular unit cell parameters $a=5.61 \mathrm{~nm}$ and $b=3.41 \mathrm{~nm}$ (Figure 10b).

One can also see two much weaker peaks corresponding to distances of 4.25 and $2.45 \mathrm{~nm}$. They can be assigned to hexagonal phase since $4.25 \approx$ $\sqrt{3} \cdot 2.45$.

There is, probably, a small amount of polymeric phthalocyanine which contains some defects which does not allow formation of crystalline phase.

Unambiguous classification of the unit cell and orientation of columns forming awaits completion by further X-ray studies.

\section{Conclusions}

The synthetic pathway of which the most difficult step was preparation of phthalocyanine bearing single terminal alkenyloxy groups has been proven successful. According to our best knowledge it is the very first synthesis of polysiloxanes bearing side phthalocyanine moieties ever published. Transition temperatures determined by TOA correspond to those determined by DSC. Therefore TOA can be considered as a very efficient and complementary tool for studies of phase transition of some discotic systems. Moreover smaller amount of the material (layers of thickness smaller than $1 \mu \mathrm{m}$ can be investigated) is required for TOA experiments. Attachment of phthalocyanine to polysiloxane chain via flexible spacer does not preclude formation of columnar organization. The spacer effectively decouples the motions of the phthalocyanine groups from the main chain. Thus the columnar ordering of the side groups is possible.

The attachment of phthalocyanine derivatives to polymer chain slows down the kinetics of self-organization (crystallization) in comparison with corresponding free phthalocyanine.

\section{Acknowledgements}

Scientific work financed by the Polish government's budget for science in the years 2010-2013. Grant of the Ministry of Science and Higher Education No 5155/B/T02/2010/39

\section{References}

[1] Law K. Y.: Organic photoconductive materials: Recent trends and developments. Chemical Reviews, 93, 449486 (1993).

DOI: $\underline{10.1021 / \mathrm{cr} 00017 \mathrm{a} 020}$

[2] Emmelius M., Pawlowski G., Vollmann H. W.: Materials for optical data storage. Angewandte Chemie International Edition in English, 28, 1445-1471 (1989). DOI: 10.1002 /anie.198914453

[3] Deng H., Mao H., Lu Z., Xu H.: Influence of molecular aggregation and orientation on the photoelectric properties of tetrasulfonated gallium phthalocyanine self-assembled on a microporous $\mathrm{TiO}_{2}$ electrode. Thin Solid Films, 315, 244-250 (1998). DOI: 10.1016/S0040-6090(97)00753-0

[4] Mortimer R. J.: Organic electrochromic materials. Electrochimica Acta, 44, 2971-2981 (1999).

DOI: 10.1016/S0013-4686(99)00046-8

[5] Li L., Tang Q., Li H., Hu W., Yang X., Shuai Z., Liu Y., Zhu D.: Organic thin-film transistors of phthalocyanines. Pure and Applied Chemistry, 80, 2231-2240 (2008).

DOI: $10.1351 / \mathrm{pac} 200880112231$

[6] Wisnieff R.: Display technology: Printing screens. Nature, 394, 225-227 (1998). DOI: $10.1038 / 28278$

[7] Crone B. K., Dodabalapur A., Sarpeshkar R., Gelperin A., Katz H. E., Bao Z.: Organic oscillator and adaptive amplifier circuits for chemical vapor sensing. Journal of Applied Physics, 91, 10140-10146 (2002).

DOI: 10.1063/1.1476084

[8] Bouvet M.: Phthalocyanine-based field-effect transistors as gas sensors. Analytical and Bioanalytical Chemistry, 384, 366-373 (2006).

DOI: $10.1007 / \mathrm{s} 00216-005-3257-6$

[9] McKeown N. B.: Phthalocyanine-containing polymers. Journal of Materials Chemistry, 10, 1979-1995 (2000). DOI: $10.1039 / \mathrm{b} 000793 \mathrm{p}$

[10] Ganicz T., Stańczyk W.: Side-chain liquid crystal polymers (SCLCP): Methods and materials. An overview. Materials, 2, 95-128 (2009).

DOI: $10.3390 / \mathrm{ma} 2010095$

[11] Armarego W. L. F., Chai C. L. L.: Purification of laboratory chemicals. Elsevier, Amsterdam (2003).

[12] Baugh S. D. P., Yang Z., Leung D. K., Wilson D. M., Breslow R.: Cyclodextrin dimers as cleavable carriers of photodynamic sensitizers. Journal of the American Chemical Society, 123, 12488-12494 (2001). DOI: $10.1021 / \mathrm{Ja} 0117090$

[13] Van der Pol J. F., Neeleman E., Zwikker J. W., Drenth W., Nolte R. J. M.: Evidence of an ordered columnar mesophase in peripherally octa- $n$-alkoxy-substituted phthalocyanines. Recueil des Travaux Chimiques des Pays-Bas, 107, 615-620 (1988).

DOI: $10.1002 / \mathrm{recl} .19881071102$ 
[14] Van der Pol J. F., Neeleman E., Nolte R. J. M., Zwikker J. W., Drenth W.: Asymmetrically substituted liquid-crystalline phthalocyanines and side-chain polymers derived from them. Die Makromolekulare Chemie, 190, 2727-2745 (1989).

DOI: $10.1002 / \mathrm{macp} .1989 .021901107$

[15] Marciniec B.: Comprehensive handbook on hydrosilylation. Pergamon Press, Oxford (1992).

[16] Geerts Y. H., Debever O., Amato C., Sergeyev S.: Synthesis of mesogenic phthalocyanine- $\mathrm{C}_{60}$ donor-acceptor dyads designed for molecular heterojunction photovoltaic devices. Beilstein Journal of Organic Chemistry, 5, 49/1-49/9 (2009).

DOI: $10.3762 /$ Bjoc.5.49

[17] Sergeyev S., Pouzet E., Debever O., Levin J., Gierschner J., Cornil J., Aspe R. G., Geerts Y. H.: Liquid crystalline octaalkoxycarbonyl phthalocyanines: Design, synthesis, electronic structure, self-aggregation and mesomorphism. Journal of Materials Chemistry, 17, 1777-1784 (2007).

DOI: 10.1039/B617856a

[18] Breiby D. W., Bunk O., Pisula W., Sølling T. I., Tracz A., Pakula T., Müllen K., Nielsen M. M.: Structure of zone-cast $\mathrm{HBC}-\mathrm{C}_{12} \mathrm{H}_{25}$ films. Journal of the American Chemical Society, 127, 11288-11293 (2005).

DOI: $10.1021 / \mathrm{Ja} 042355 \mathrm{e}$
[19] Tracz A., Makowski T., Masirek S., Pisula W., Geerts Y. H.: Macroscopically aligned films of discotic phthalocyanine by zone casting. Nanotechnology, 18, 485303/1-485303/5 (2007).

DOI: $10.1088 / 0957-4484 / 18 / 48 / 485303$

[20] Anokhin D. V., Rosenthal M., Makowski T., Tracz A., Bras W., Kvashnina K., Ivanov D. A.: Comparative structural study of thin films of a columnar liquid crystal aligned by mechanical shearing and zone casting. Thin Solid Films, 517, 982-985 (2008).

DOI: $10.1016 / \mathrm{j} . \mathrm{tsf} .2008 .07 .012$

[21] Tant J., Geerts Y. H., Lehmann M., De Cupere V., Zucchi G., Laursen B. W., Bjørnholm T., Lemaur V., Marcq V., Burquel A., Hennebicq E., Gardebien F., Viville P., Beljonne D., Lazzaroni R., Cornil J.: Liquid crystalline metal-free phthalocyanines designed for charge and exciton transport. The Journal of Physical Chemistry B, 109, 20315-20323 (2005). DOI: $10.1021 / \mathrm{Jp} 0547780$

[22] Tant J., Geerts Y. H., Lehmann M., De Cupere V., Zucchi G., Laursen B. W., Bjørnholm T., Lemaur V., Marcq V., Burquel A., Hennebicq E., Gardebien F., Viville P., Beljonne D., Lazzaroni R., Cornil J.: Liquid crystalline metal-free phthalocyanines designed for charge and exciton transport (Correction). The Journal of Physical Chemistry B, 110, 3449 (2006).

DOI: $10.1021 / \mathrm{Jp} 060109 \mathrm{e}$ 